\title{
Poprawa wartości pokarmowej ziarna pszenicy jarej poprzez siewy mieszanin odmianowych
}

\author{
Improvement of the spring wheat nutritional value by sowing variety mixtures
}

\author{
Danuta Boros $^{1 凶}$, Magdalena Wiśniewska1 ${ }^{1}$, Marlena Gzowska1 ${ }^{1}$ Józef \\ Zych $^{2}$, Edward Gacek ${ }^{2}$
}

\author{
1 Samodzielna Pracownia Oceny Jakości Produktów Roślinnych, IHAR-PIB, 05-870 Radzików, \\ ${ }^{2}$ Centralny Ośrodek Badania Roślin Uprawnych, 63-022 Słupia Wielka, \\ $\triangle$ e-mail: d.boros@ihar.edu.pl
}

\begin{abstract}
Praca miała na celu określenie zawartości substancji odżywczych i bioaktywnych w ziarnie mieszanin odmianowych, dwu i trójskładnikowych, pszenicy jarej w porównaniu do ziarna odmian wchodzących w skład tych mieszanin z siewu czystego oraz wykazanie czy ten sposób produkcji ziarna umożliwia, oprócz lepszego plonowania, także poprawę jego wartości pokarmowej. Materiał badawczy stanowiło ziarno 14 odmian oraz 60 mieszanek, w tym 10 dwuskładnikowych, z lat zbioru 2014, 2016 i 2018. Oznaczono zawartość białka, lipidów, składników mineralnych i skrobi, składających się na substancje odżywcze, a także błonnika pokarmowego, jego podstawowych składników oraz związków fenolowych, włączając alkilorezorcynole jako substancje bioaktywne w ziarnie zbóż. Wyniki badań wykazały, że poprawa wartości użytkowej ziarna jest możliwa poprzez uprawę mieszanek odmianowych pszenicy jarej. Czynnik genetyczny miał istotny wpływ na zawartość substancji odżywczych oraz kompleksu błonnika pokarmowego w ziarnie mieszanin odmianowych pszenicy jarej. Identyfikacja odpowiednich odmian do siewów mieszanych jest niezbędna do poprawy wartości użytkowej ziarna pszenicy jarej.
\end{abstract}

Słowa kluczowe: składniki odżywcze, składniki bioaktywne, mieszaniny dwuskładnikowe, mieszaniny trójskładnikowe, komponenty mieszanin

\begin{abstract}
The aim of the study was to determine the content of nutrients and bioactive substances in two- and three-variety mixtures of spring wheat in comparison to varieties growing in pure stand and to demonstrate whether this method of grain production allows, in addition to better yielding, improvement of its nutritional value. The material for analysis consisted of 14 varieties and 60 varietal mixtures, including 10 two-component mixtures harvested in the years 2014, 2016 and 2018. The content of protein, lipids, minerals and starch, constituting nutrients and dietary fibre, including its basic components and phenolic compounds, was determined as bioactive substances of cereal grains. The results showed that the improvement of the end-use value is possible by cultivating spring wheat varietal mixtures. The genetic factor had a significant impact on the content of nutrients and the complex of dietary fibre in the variety mixture of spring wheat. Identification of suitable varieties for mixed sowing is necessary to improve the nutritional value of spring wheat.
\end{abstract}

Keywords: nutrients, bioactive components, two-component mixtures, three-component mixtures, mixture components

\section{Wstęp}

Mieszanki odmianowe w obrębie tego samego gatunku zbóż budzą ogromne zainteresowanie w Polsce i w Unii Europejskiej z uwagi na ich przydatność do uprawy $\mathrm{w}$ systemie integrowanej produkcji rolniczej, umożliwiającym uzyskanie płodów rolnych o najwyższych wartościach żywieniowych oraz bezpiecznych dla zdrowia ludzi. Mieszanka odmianowa jest zdefiniowana jako przeznaczona do zasiewów zamierzona mieszanina co najmniej dwóch odmian, pozwalająca producentom zbóż zmaksymalizować w uprawie indywidualne dobre cechy każdej z odmian, a zamaskować cechy mniej korzystne (Dai i in., 2012). W przypadku zbóż jarych w uprawie najczęściej stosowane są mieszaniny odmianowe $\mathrm{w}$ obrębie pszenicy i jęczmienia. Uprawa mieszanin odmianowych zwiększa bioróżnorodność i przez to zapewnia lepsze wykorzystanie zasobów środowiska, z jednoczesnym zmniejszeniem występowania chorób i szkodników (Gacek i in., 1996; Finckh i in., 2000; Leszczyńska, 2010; Vera i in., 2013). W dążeniu do osiągnięcia tych celów bardzo ważny jest dobór odmian, nie może on być przypadkowy (Cheema i in., 1988; Nadziak, Tratwal, 2012). Pozytywny efekt siewów mieszanych może być osiągnięty tylko w sytuacji korzystnej interakcji pomiędzy odmianami wchodzącymi w skład mieszanki (Kiær i in., 2009), w połączeniu z warunkami 
siedliskowymi ich uprawy (Leszczyńska, 2010). Gdy dobór komponentów jest właściwy, stresy biotyczne i abiotyczne są w całym okresie wegetacji lepiej buforowane, $\mathrm{w}$ efekcie plonowanie jest bardziej stabilne, a uzyskane plony ziarna lepszej jakości i najczęściej większe niż odmian wchodzących w skład mieszanki z siewu czystego (Finckh i in., 2000; Kiær i in., 2009). Głównym kryterium doboru odmian do mieszanin jest zróżnicowanie pod względem odporności na najważniejsze choroby, jak również podobna wysokość roślin i zbliżony okres dojrzewania (Gacek i in., 1996; Nadziak, Tratwal, 2012). Dotychczasowe prace badawcze wykazały, że im mieszanina była bardziej zróżnicowana genetycznie tym odnotowywano mniejsze natężenie chorób, sięgające nawet $60-80 \%$ w porównaniu do ich występowania na odmianach komponentach rosnących w siewie czystym (Gacek $\mathrm{i}$ in., 1996). W odniesieniu do plonowania, kompensacja nie była tak duża, w zakresie od $1 \%$ do $15 \%$, w zależności od mieszaniny użytych odmian i warunków środowiska (Gacek i in., 1996; Finckh $\mathrm{i}$ in., 2000; Kiær i in., 2009).

Polska ma długą tradycję uprawy na dużą skalę mieszanek zbożowych. Jest to jedna z cech wyróżniających polskie rolnictwo w Unii Europejskiej. Obecnie mieszanki zbożowe zajmują 3-4 miejsce w strukturze zasiewów zbóż, wyprzedzając takie zboża podstawowe jak jęczmień i owies, a dorównując żytu. Według danych GUS (2019), w 2019 roku powierzchnia zasiewów mieszanek zbożowych wyniosła 930 tys. ha. W uprawie przeważają mieszanki międzygatunkowe zbóż jarych, jęczmienia, pszenicy i owsa, z przeznaczeniem na cele paszowe. Ta sytuacja ulega zmianie na korzyść mieszanin odmianowych, $\mathrm{z}$ uwagi na negatywny wpływ owsa na wartość paszową mieszanki. Mieszaniny odmianowe pszenicy zyskują zainteresowanie jako zboże chlebowe (Żmijewski, 2004; Lee i in., 2006; Jost i in., 2015). W Szwajcarii ponad $10 \%$ zasiewów pszenicy chlebowej stanowią mieszaniny odmianowe (Jost $\mathrm{i}$ in., 2015).

Celem badań było określenie zawartości związków odżywczych i bioaktywnych w ziarnie mieszanin odmianowych, dwu i trójskładnikowych, pszenicy jarej w porównaniu do ziarna odmian wchodzących w skład tych mieszanin z siewu czystego oraz wykazanie na tej podstawie czy korzystny efekt może być związany z niektórymi z nich. Badania są częścią zadania realizowanego w ramach Programu Wieloletniego IHAR-PIB, dotyczącego doboru odmian zbóż i odmian roślin strączkowych do siewów mieszanych, w różnych warunkach agro-klimatycznych Polski.

\section{Material i Metody}

Materiał do badań pochodził z doświadczeń polowych założonych w sieci doświadczalnej COBORU w 2014, 2016 i 2018 roku, w trzech Stacjach Oceny Odmian: Przecławiu, Słupi Wielkiej i Sulejowie (tab. 1). W roku 2014 w doświadczeniach było pięć odmian pszenicy jarej oraz 10 mieszanek dwuskładnikowych i 10 mieszanek trójskładnikowych tych odmian. W porównaniu do odmian z siewu czystego, mieszanki trójskładnikowe plonowały lepiej oraz wykazały większą zdrowotność łanu i ziarna, stąd w następnych latach do doświadczeń włączono tylko 20 kombinacji mieszanin trójskładnikowych sześciu odmian.

Material badawczy

Material

\begin{tabular}{|c|c|c|c|c|}
\hline \multirow{2}{*}{$\begin{array}{l}\text { Nazwa odmian } \\
\text { Name of varieties }\end{array}$} & \multirow{2}{*}{$\begin{array}{c}\text { Liczba mieszanek } \\
\text { dwuskładnikowych } \\
\text { No of two component } \\
\text { mixtures }\end{array}$} & \multirow{2}{*}{$\begin{array}{c}\text { Liczba mieszanek } \\
\text { trójskładnikowych } \\
\text { No of three component } \\
\text { mixtures }\end{array}$} & \multicolumn{2}{|c|}{$\begin{array}{l}\text { Doświadczenie polowe } \\
\text { Field trial }\end{array}$} \\
\hline & & & $\begin{array}{l}\text { Lokalizacja } \\
\text { Location }\end{array}$ & $\begin{array}{l}\text { Rok zbioru } \\
\text { Harvest year }\end{array}$ \\
\hline $\begin{array}{c}\text { Arabella, Izera, Ostka } \\
\text { Smolicka, Struna, Tybalt } \\
(5)\end{array}$ & 10 & 10 & $\begin{array}{l}\text { Przecław, } \\
\text { Słupia Wielka, } \\
\text { Sulejów, }\end{array}$ & 2014 \\
\hline $\begin{array}{c}\text { Arabella, Goplana, } \\
\text { Harenda, Kamelia, KWS } \\
\text { Torridon, Mandaryna (6) }\end{array}$ & - & 20 & $\begin{array}{l}\text { Przecław, } \\
\text { Słupia Wielka, } \\
\text { Sulejów }\end{array}$ & 2016 \\
\hline $\begin{array}{c}\text { Goplana, Frajda, Nimfa, } \\
\text { Harenda, Rusałka, Jarlanka } \\
(6)\end{array}$ & - & 20 & $\begin{array}{l}\text { Przecław, } \\
\text { Słupia Wielka, } \\
\text { Sulejów }\end{array}$ & 2018 \\
\hline
\end{tabular}




\section{Opis doświadczeń polowych}

Doświadczenia polowe prowadzono według metodyki stosowanej w badaniach WGO (COBORU, 2014, 2015). Założono je jako jednoczynnikowe, w niekompletnych, blokowych układach jedno-rozkładalnych, w trzech powtórzeniach. Chemiczna ochrona roślin obejmowała zaprawianie nasion przed siewem, stosowanie herbicydów, a w przypadku wystąpienia szkodników także insektycydów. Nie stosowano natomiast chemicznej ochrony roślin przed chorobami i wyleganiem. Nawożenie mineralne było zróżnicowane w poszczególnych punktach doświadczalnych, dostosowane do jakości gleby, rodzaju przedplonu i zasobności gleby w składniki mineralne. Powierzchnia pojedynczego poletka wynosiła $15 \mathrm{~m}^{2}$. Przy ustalaniu ilości wysiewu uwzględniano masę 1000 ziarniaków i zdolność kiełkowania ziarna poszczególnych odmian. Obsada ziarna dla wszystkich odmian w siewie czystym i siewie mieszanym wynosiła $450 \mathrm{szt} . \mathrm{m}^{2}$. $\mathrm{W}$ mieszaninach udział każdej z odmian był taki sam, po $225 \mathrm{szt} . / \mathrm{m}^{2} \mathrm{w}$ dwuskładnikowych i po 150 szt. $/ \mathrm{m}^{2} \mathrm{w}$ trójskładnikowych. Przebieg warunków pogodowych, jako średnie miesięczne wartości temperatury powietrza i sumy opadów z danego roku wegetacji z trzech miejscowości, przedstawiono w tabeli 2 (COBORU, 2014, 2015; 2016; 2018).

Warunki pogodowe w trzech sezonach wegetacyjnych, z których pobrano ziarno do badań analitycznych, były zróżnicowane i z pewnością miały wpływ na skład chemiczny ziarna. Sezon wegetacyjny w 2014 roku wyróżniał się bardzo dużymi opadami deszczu w miesiącu maju $(117 \mathrm{~mm})$ i sierpniu $(119 \mathrm{~mm})$ oraz wysoką średnią temperaturą powietrza w lipcu. W 2015 roku odnotowano większe opady w lipcu (169 mm), a mniejsze w maju (39 $\mathrm{mm}$ ) oraz wysokie temperatury powietrza w miesiącach letnich. Z kolei rok 2018 charakteryzował się bardzo suchym oraz najpierw zimnym a potem gorącym początkiem wiosny. Suma opadów w marcu i kwietniu wyniosła $35 \mathrm{~mm}$ i $20 \mathrm{~mm}$, przy średnich miesięcznych temperaturach odpowiednio $-0,4 C^{\circ}$ oraz $14,2 C^{\circ}$. W roku tym wysokie temperatury powietrza $\mathrm{z}$ mniejszymi opadami deszczu utrzymywały się przez cały sezon wegetacyjny.

\section{Analizy chemiczne}

W laboratorium przygotowano próbkę analityczną, poprzez zsypanie ziarna każdej odmiany lub mieszaniny odmianowej $\mathrm{w}$ równych proporcjach wagowych z każdej z trzech miejscowości zbioru ziarna. Tak przygotowane próbki ziarna zmielono na młynku laboratoryjnym Cyclotec ${ }^{\mathrm{TM}}$, firmy Foss, wyposażonym w sito o wielkości oczek 0,5 mm. Oznaczono w nich zawartość suchej masy (nr 44-16.01), białka (nr 46-11.02), składników mineralnych (nr 08-01.01) i skrobi przyswajalnej (nr 76-11) metodami standardowymi wg AACC (2011) oraz lipidów ogółem grawimetrycznie po ekstrakcji kwaśnej, według Marchello i in. (1971). Suma tych składników składała się na zawartość składników odżywczych (SSO). Oznaczono ponadto zawartość ligniny Klasona i składników bioaktywnych, takich jak: nieskrobiowych polisacharydów (NSP), z podziałem na frakcję rozpuszczalną (S-NSP) i nierozpuszczalną (I-NSP), w tym $\beta$-glukanu oraz arabinoksylanów (TAX) z podziałem na ekstrahowalne (WE-AX) i nieekstrahowalne w wodzie (WUE-AX), polifenoli ogółem (TPC) i alkilorezorcynoli (AR). NSP oznaczono metodą chromatografii

Warunki pogodowe w sezonie wegetacyjnym w latach 2014, 2016 i 2018

Weather conditions during growing season in years 2014, 2016 and 2018

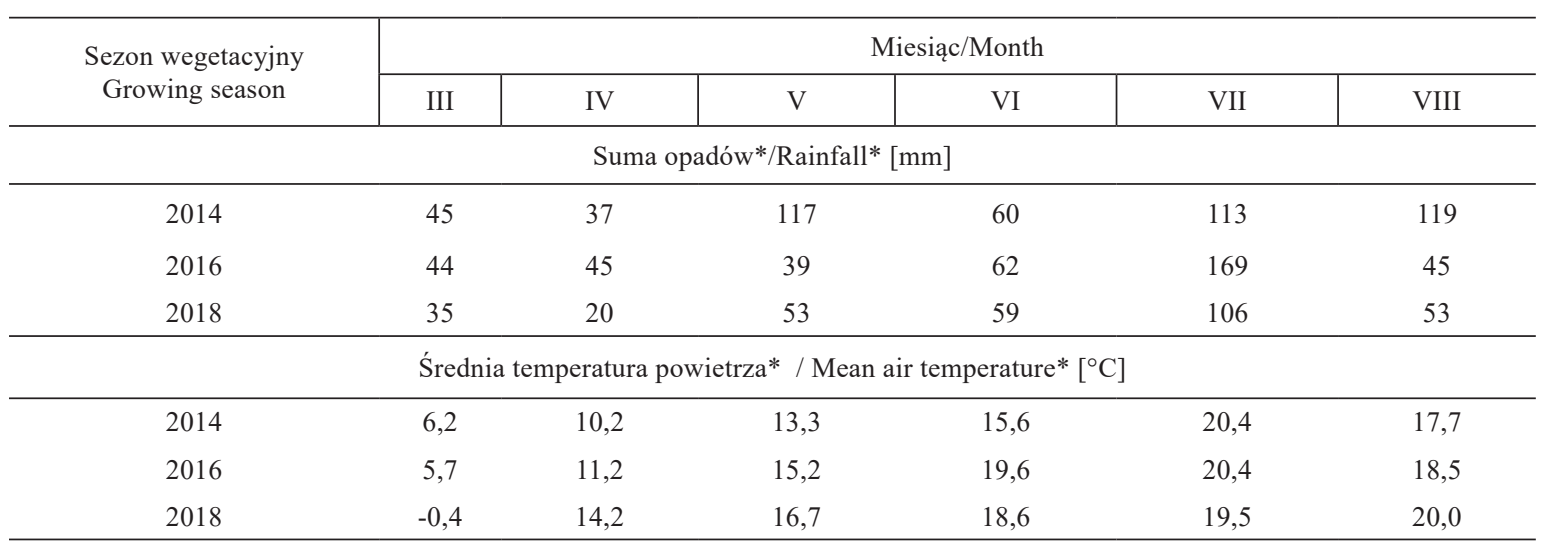

*Wartości średnie z trzech lokalizacji/Mean values from three locations 
gazowej według Englysta i Cummingsa (1984), która stanowi sumę cukrów: arabinozy, ksylozy, mannozy, galaktozy i glukozy, a $\beta$-glukan kolorymetrycznie zgodnie z metodą nr 32-23 wg AACC (2011). Ligninę Klasona analizowano metoda grawimetryczną jako pozostałość po trawieniu $72 \%$ kwasem siarkowym (Theander, Westerlund, 1986). Z zawartości NSP i ligniny wyliczono zawartość błonnika pokarmowego (TDF), zgodnie z metodą nr 32-25, AACC (2011). Oznaczanie całkowitej zawartości związków fenolowych (TPC) wykonano metodą kolorymetryczną z wykorzystaniem reagentu Folin-Ciocalteu (Singleton i Rossi, 1965). Wyniki przedstawiono jako ekwiwalent miligramów kwasu galusowego (GAE) na g suchej masy próbki. Alkilorezorcynole ekstrahowano z całego ziarna acetonem i oznaczono kolorymetrycznie według Tłuścika i in. (1981) na podstawie reakcji barwnej $\mathrm{z}$ solą diazoniową Fast Blue $\mathrm{B} \mathrm{ZnCl} 2$ przy długości fali $520 \mathrm{~nm}$ (Gajda i in., 2008). Każda analiza była wykonana w co najmniej dwóch powtórzeniach, błąd analizy składników odżywczych nie przekraczał $3 \%$ a pozostałych $4 \%$. Uzyskane wyniki przeliczono na suchą masę.

Wyniki opracowano statystycznie, wykorzystując do tego celu analizę wariancji modelu ANOVA, oddzielnie dla materiału z każdego roku badań (Statistica 13.3). Dodatkowo wyliczono wspó1czynniki korelacji liniowych Pearsona między wybranymi składnikami ziarna, których istotność testowano przy poziomie $\mathrm{p}<0,05$ oraz $\mathrm{p}<0,01$ (wyniki omówione w tekście). Procedurę porównań wielokrotnych Tukeya - Kramera zastosowano w odniesieniu do odmian i mieszanin.

\section{Wyniki i Dyskusja}

Materiał badawczy dobrano i przygotowano do analiz chemicznych w sposób umożliwiający sprawdzenie wpływu siewu mieszanego na wartość pokarmową ziarna jak największej liczby odmian pszenicy jarej. Analizom chemicznym poddano ziarno 14 odmian i 60 kombinacji mieszankowych, pochodzace ze zbioru w latach 2014, 2016 i 2018, z doświadczeń polowych założonych w każdym roku w trzech lokalizacjach. Przy wyborze odmian do siewów mieszanych brano pod uwagę pochodzenie (w pierwszej kolejności odmiany krajowe), wysokie plonowanie i zróżnicowanie odporności na choroby (COBORU, 2014 i 2015; 2016; 2018).

Średnie plony mieszanin w poszczególnych latach badań nie różniły się istotnie od średniego plonu odmian w siewie czystym, choć w latach 2014 i 2018 były znacznie wyższe niż w 2016 roku (tab. 3). Niesprzyjające warunki pogodowe w okresie wegetacji miały prawdopodobnie wpływ na niższe plonowanie w 2016 roku (tab. 2). Spośród badanych odmian i mieszanek, najwyższy plon w roku 2014 odnotowano dla mieszanki dwuskładnikowej Arabella+Struna (75,9 dt z ha), a najniższy (o ponad $8 \mathrm{dt}$ z ha) dla odmiany Tybalt (COBORU, 2014, 2015). W roku 2016 najwyżej plonowały odmiany Goplana i Harenda (55,9 i 55,6 dt z ha), a także mieszanina składająca się $\mathrm{z}$ tych samych dwóch odmian oraz odmiany Mandaryna (57,9 dt z ha), natomiast najniższe plony uzyskano $\mathrm{w}$ przypadku mieszaniny Arabella+Harenda+KWS Torridon oraz Arabella+Goplana+Kamelia (nieco powyżej $53 \mathrm{dt} \mathrm{z} \mathrm{ha)}$ (COBORU, 2016). W roku 2018 odnotowano bardzo duże zróżnicowanie plonowania w poszczególnych

Plonowanie pszenicy jarej w latach 2024, 2026 i 2018* [dt-ha ${ }^{-1}$ ]

Grain yield of spring wheat in 2014, 2016 and 2018* [dt-ha ${ }^{-1}$ ]

\begin{tabular}{|c|c|c|c|}
\hline \multirow{2}{*}{ Rodzaj zasiewu } & \multicolumn{3}{|c|}{ Rok zbioru/Harvest year } \\
\hline & 2014 & 2016 & 2018 \\
\hline $\begin{array}{c}\text { Odmiany w siewie czystym } \\
\text { Pure variety }\end{array}$ & 71,8 & 54,8 & 74,7 \\
\hline $\begin{array}{l}\text { Mieszanki dwuskładnikowe } \\
\text { Two component mixture }\end{array}$ & 71,8 & - & - \\
\hline $\begin{array}{l}\text { Mieszanki trójskładnikowe } \\
\text { Three component mixture }\end{array}$ & 72,1 & 54,8 & 74,7 \\
\hline \multirow{2}{*}{$\begin{array}{l}\text { Plon średni z } 3 \text { lat dla miejscowości } \\
\text { Average 3-year yield per location }\end{array}$} & Przecław & Słupia Wielka & Sulejów \\
\hline & 69,7 & 76,6 & 54,0 \\
\hline $\begin{array}{l}\text { Zakres w latach } \\
\text { Range in years }\end{array}$ & $59,3-83,7$ & $55,9-88,6$ & $46,4-67,8$ \\
\hline
\end{tabular}

*Dane COBORU/COBORU data 
lokalizacjach od 47,5 dt z ha w Sulejowie do 85,2 dt z ha w Słupi Wielkiej. Najwyższy plon średni uzyskano dla mieszanek Goplany, Harendy z Frajdą oraz z Nimfą (76,9 i 76,3 dt z ha). Wysoko plonowała również odmiana Goplana (75,8 dt $\mathrm{z}$ ha), uprawiana $\mathrm{w}$ siewie czystym natomiast najgorzej pod względem tej cechy oceniona została mieszanka Frajda+Harenda+Rusałka (71,4 dt z ha) (COBORU, 2018). Odmiany pszenicy jarej, wchodzące w skład mieszanin odmianowych należały w przeważającej większości (11 odmian) do klasy pszenic chlebowych jakościowych A, a 3 odmiany (Frajda, Harenda i Kamelia) reprezentowały pszenice chlebowe klasy B (COBORU, 2020).
Ziarno pszenicy jest podstawowym surowcem w przemyśle młynarsko-piekarskim, a także cennym składnikiem mieszanek paszowych dla wszystkich grup zwierząt gospodarskich. Ocena podstawowego składu chemicznego, tj. białka, składników mineralnych, lipidów i skrobi, składających się na sumę substancji odżywczych (SSO), jest pierwszym wskaźnikiem umożliwiającym określenie wartości pokarmowej, przemiałowej i wypiekowej ziarna pszenicy (Hoseney, 1994). W ocenie wartości technologicznej linii hodowlanych oraz nowych odmian pszenicy skutecznym wstępnym kryterium jakościowym jest procentowa zawartość białka w ziarnie, gdyż przekłada się

Tabela 4

Table 4

Zawartości składników odżywczych w ziarnie odmian oraz ich mieszanin odmianowych pszenicy jarej (wartości średnie z poszczególnych lat zbioru, w\% s.m.)

Content of nutrients in varieties and their variety mixtures of spring wheat (mean values for particular harvest years, on DM \%)

\begin{tabular}{|c|c|c|c|c|c|}
\hline $\begin{array}{l}\text { Odmiany, mieszanki } \\
\text { Varieties, mixtures }\end{array}$ & $\begin{array}{l}\text { Białko } \\
\text { Protein }\end{array}$ & $\begin{array}{l}\text { Lipidy } \\
\text { Lipids }\end{array}$ & $\begin{array}{l}\text { Składniki } \\
\text { mineralne } \\
\text { Minerals }\end{array}$ & $\begin{array}{l}\text { Skrobia } \\
\text { Starch }\end{array}$ & $\mathrm{SSO}^{*}$ \\
\hline \multicolumn{6}{|c|}{2014 rok zbioru / 2014 harvest year } \\
\hline $\begin{array}{l}\text { Odmiany } \\
\text { Varieties }\end{array}$ & $13,4 \pm 0,4^{\mathrm{a}}$ & $2,58 \pm 0,1$ & $1,58 \pm 0,1$ & $65,3 \pm 0,5^{b}$ & $82,9 \pm 0,8$ \\
\hline $\begin{array}{l}\text { Mieszaniny dwuskładnikowe } \\
\text { Two component mixtures }\end{array}$ & $13,4 \pm 0,4^{\mathrm{a}}$ & $2,63 \pm 0,1$ & $1,57 \pm 0,0$ & $65,6 \pm 0,5^{\mathrm{ab}}$ & $83,2 \pm 0,7$ \\
\hline $\begin{array}{l}\text { Mieszaniny trójskładnikowe } \\
\text { Three component mixtures }\end{array}$ & $13,0 \pm 0,4^{b}$ & $2,61 \pm 0,1$ & $1,56 \pm 0,1$ & $66,2 \pm 0,9^{\mathrm{a}}$ & $83,4 \pm 0,8$ \\
\hline $\begin{array}{l}\text { Prawdopodobieństwo } \\
\text { Probability }\end{array}$ & 0,0001 & 0,0001 & 0,0001 & 0,086 & 0,059 \\
\hline NIR/LSD & 0,301 & 0,098 & 0,086 & $\mathrm{~ns}$ & $\mathrm{~ns}$ \\
\hline \multicolumn{6}{|c|}{2016 rok zbioru / 2016 harvest year } \\
\hline $\begin{array}{l}\text { Odmiany } \\
\text { Varieties }\end{array}$ & $14,3 \pm 0,4$ & $2,79 \pm 0,1$ & $1,45 \pm 0,0$ & $60,8 \pm 1,0$ & $79,3 \pm 0,7$ \\
\hline $\begin{array}{l}\text { Mieszaniny trójskładnikowe } \\
\text { Three component mixtures }\end{array}$ & $14,3 \pm 0,2$ & $2,84 \pm 0,1$ & $1,44 \pm 0,1$ & $60,3 \pm 0,7$ & $78,9 \pm 0,7$ \\
\hline $\begin{array}{l}\text { Prawdopodobieństwo } \\
\text { Probability }\end{array}$ & 0,0001 & 0,0001 & 0,0015 & 0,006 & 0,047 \\
\hline NIR/LSD & 0,349 & 0,255 & 0,069 & 2,813 & 2,943 \\
\hline \multicolumn{6}{|c|}{2018 rok zbioru / 2018 harvest year } \\
\hline $\begin{array}{l}\text { Odmiany } \\
\text { Varieties }\end{array}$ & $12,4 \pm 0,1^{b}$ & $2,60 \pm 0,1$ & $1,58 \pm 0,1$ & $60,7 \pm 1,4^{\mathrm{a}}$ & $77,3 \pm 1,5^{\mathrm{a}}$ \\
\hline $\begin{array}{l}\text { Mieszaniny trójskładnikowe } \\
\text { Three component mixtures }\end{array}$ & $12,7 \pm 0,2^{\mathrm{a}}$ & $2,62 \pm 0,1$ & $1,62 \pm 0,1$ & $59,2 \pm 1,1^{\mathrm{b}}$ & $76,2 \pm 1,0^{\mathrm{b}}$ \\
\hline $\begin{array}{l}\text { Prawdopodobieństwo } \\
\text { Probability }\end{array}$ & 0,4659 & 0,0001 & 0,0001 & 0,0033 & 0,0018 \\
\hline NIR/LSD & ns & 0,168 & 0,117 & 4,398 & 3,919 \\
\hline
\end{tabular}

*SSO - suma skladników odżywczych; SSO - sum of nutrients 
ona na wydajność glutenu mokrego i tym samym na wartość wypiekową mąki pszennej (Cygankiewicz, 1997; Stępniewska, Słowik, 2016). Pszenica jara w porównaniu do pszenicy ozimej cechuje się na ogół lepszą wartością wypiekową, ale mniejszą wartością przemiałową, co wiąże się z większą zazwyczaj zawartością w ziarnie białka a mniejszą skrobi (Biel, Maciorowski, 2012; Cacak-Pietrzak $\mathrm{i}$ in., 2014; Boros i in., 2015). Są jednakże nieliczne dane wskazujące na większą zawartość białka w ziarnie form ozimych na tle form jarych pszenicy (Stępniewska, Słowik, 2016), na co wpływ najprawdopodobniej mają dobór i ilość ocenianych genotypów oraz warunki pogodowe w okresie wegetacji. W przeprowadzonych badaniach nie stwierdzono istotnych różnic $(\mathrm{p}>0,05)$ pod względem SSO w ziarnie odmian i mieszanin odmianowych pochodzącym ze zbioru 2014 roku (tab. 4). Istotne różnice $(\mathrm{p}<0,05)$ w SSO wykazano natomiast w materiale zebranym w 2016 i 2018 roku. W odniesieniu do ziarna ze zbioru 2018 roku różnice istotne SSO były także między odmianami z siewu czystego, a mieszaninami trójskładnikowymi tych odmian. Ziarno mieszanin trójskładnikowych $\mathrm{z}$ tego roku zbioru miało średnio o 1,1 jednostek procentowych mniej SSO niż średnia wartość w ziarnie komponentów. Ogólnie ziarno z 2018 roku charakteryzowało się najmniejszą wartością SSO $(76,4 \%)$ na skutek małej zawartości białka (12,6\%) i skrobi $(59,6 \%)$ $\mathrm{w}$ porównaniu do ziarna pszenicy z wcześniejszych lat zbioru. Genotyp miał z całą pewnością duży wpływ na różnice w zawartości białka, skrobi i w efekcie SSO w latach zbioru ziarna. Nie można wykluczyć jednakże wpływu zmiennych warunków pogodowych w okresie wegetacji na zróżnicowanie zawartości podstawowych składników pokarmowych (Lee i in., 2006). Odmiany Goplana i Harenda, pochodzące z doświadczeń przeprowadzonych w latach 2016 i 2018, różniły się znacznie pod względem zawartości białka w ziarnie, mimo że pochodziło ono z tych samych warunków glebowych. W porównywanych latach zbioru, 2016 i 2018, ziarno odmiany Goplana zawierało białka odpowiednio $13,8 \%$ vs. $12,6 \%$, a odmiany Harenda $14,1 \%$ vs.12,3\%. Suchy i ciepły koniec kwietnia oraz wysokie temperatury panujące w maju 2018 roku spowolniły rozwój roślin, co prawdopodobnie rzutowało na dalsze fazy wzrostu takie, jak wykształcenie źdźbeł i kłosów (COBORU, 2018). Podobnie dużą różnicę w zawartości białka odnotowano w przypadku ziarna odmiany Arabella z roku zbioru 2014 i 2016, odpowiednio 13,3\% vs. 14,6\%. Ogólnie stwierdzono istotne różnice w zawartości białka w ziarnie odmian i mieszanin ze zbioru
2014 i 2018, a w odniesieniu do skrobi w ziarnie pochodzącym ze zbioru 2016 i 2018 roku. Ponadto istotne różnice odnotowano między odmianami a mieszaninami w zawartości białka i skrobi w materiale pochodzącym ze zbioru 2014 i 2018 roku. Takich różnic między odmianami i mieszaninami nie wykazano w ziarnie z 2016 roku zbioru. W zestawie próbek ziarna ze zbioru 2014 roku, mieszaniny trójskładnikowe miały średnio mniej białka $(13,0 \%$ vs. $13,4 \%)$, ale więcej skrobi $(66,2 \%$ vs. $65,4 \%$ ) w porównaniu do średniej ilości obu tych składników w mieszaninach dwuskładnikowych oraz ich odmianach komponentach. Mieszaninami o największej zawartości białka w ziarnie z 2014 roku zbioru (po 13,8\%) były Arabella+Tybalt oraz Izera+Tybalt. Ostka Smolicka była odmianą o największej zawartości białka (13,8\%), a Izera o najmniejszej (12,7\%). Ziarno ze zbioru 2016 roku charakteryzowało się dużą zawartością białka (średnio $14,3 \%$ ), jednakże małą skrobi (średnio 60,5\%). Odmiany Kamelia, KWS Torridon i Arabella miały tego składnika najwięcej (14,7\% do 14,6\%), a wśród mieszanek odmianowych, mieszanina skomponowana $\mathrm{z}$ tych trzech odmian (14,7\%). Natomiast mieszanina składająca się z odmian o najmniejszej zawartości białka (poniżej 14\%), tj. z Goplany, Harendy i Mandaryny, miała białka najmniej $(13,9 \%)$ wśród mieszanin z 2016 roku. W ziarnie uzyskanym w 2018 roku stwierdzono niewielkie zróżnicowanie (1\%) zawartości białka zarówno wśród odmian oraz mieszanin odmianowych. Odmiany Goplana, Jarlanka i Nimfa były odmianami o największej ilości białka $(12,6 \%)$, a wśród mieszanek, mieszanina Jarlanki i Nimfy, odpowiednio z Harendą (13,1\%) oraz z Goplaną i z Frajdą (po 12,9\%). W badaniach $\mathrm{m}$. in. wartości technologicznej ziarna czterech odmian pszenicy jarej uprawianej w siewie czystym i mieszanym, pochodzącego z produkcji w latach 1996-1998, nie wykazano istotnych różnic w zawartości białka między odmianami i mieszaninami (Żmijewski, 2004). Biorąc pod uwagę zawartość białka jako jeden z podstawowych wyróżników charakteryzujących wartość wypiekową pszenicy, można stwierdzić, że ziarno każdej z badanych mieszanin odmianowych, jak również każdej z odmian z siewu czystego spełniało wymagania surowcowe. Jak podaje Rothkaehl (2015) ziarno przeznaczone do przemiału na mąki wypiekowe powinno zawierać białka nie mniej niż 11,5\% w suchej masie. W przeprowadzonych badaniach w każdym roku stwierdzono ujemną korelację między zawartością białka i skrobi (tab. 6). W odniesieniu do ziarna $\mathrm{z}$ lat zbioru 2016 i 2018 korelacje były istotne $(r=-0,524$ i r=-0,450). 
Podobne zależności między tymi dwoma składni- i wynika z różnic wydatkowania energetycznego kami ziarna uzyskano w przypadku innego zesta- na ich syntezę. Roślina zbożowa na syntezę białwu odmian pszenicy ozimej oraz jarej (Boros i in., ka potrzebuje ponad dwukrotnie więcej energii niż 2014), a także dla próbek mąk pszennych zarów- na syntezę skrobi, wyrażona w jednostkach glukono handlowych, jak i pochodzących z przemiału zowych wynosi odpowiednio 2,5 oraz 1,2 (Munck, laboratoryjnego ziarna pszenicy (Achremowicz 1987). Skrobia, główny składnik zapasowy ziarna i in., 2010). Ujemna korelacja między zawartością zbóż, w żywności lub paszach stanowi doskonałe białka i skrobi w ziarnie zbóż jest znana od dawna źródło energii, a jej hydroliza odgrywa znaczącą

Tabela 5

Table 5

Zawartość włókna pokarmowego i jego składników w ziarnie odmian oraz ich mieszanin odmianowych dwu i trójskładnikowych pszenicy jarej (wartości średnie z poszczególnych lat zbioru, w\% s.m.)

Content of nutrients in varieties and their variety mixtures of spring wheat (mean values for particular harvest years, on DM \%)

\begin{tabular}{|c|c|c|c|c|c|c|c|c|c|}
\hline $\begin{array}{l}\text { Odmiany, mieszanki } \\
\text { Varieties, mixtures }\end{array}$ & S-NSP & I-NSP & NSP & $\begin{array}{l}\text { Lignina } \\
\text { Lignin }\end{array}$ & $\mathrm{TDF}$ & WE-AX & WUE-AX & TAX & $\begin{array}{l}\beta \text {-glukan } \\
\beta \text {-glucan }\end{array}$ \\
\hline \multicolumn{10}{|c|}{2014 rok zbioru / 2014 harvest year } \\
\hline $\begin{array}{l}\text { Odmiany } \\
\text { Varieties }\end{array}$ & $2,10 \pm 0,2$ & $7,07 \pm 0,5$ & $9,17 \pm 0,6$ & $2,87 \pm 0,1^{\mathrm{ab}}$ & $12,0 \pm 0,5$ & $1,11 \pm 0,2$ & $4,20 \pm 0,3$ & $5,31 \pm 0,4$ & $0,73 \pm 0,1$ \\
\hline $\begin{array}{c}\text { Mieszaniny } \\
\text { dwuskładnikowe } \\
\text { Two component } \\
\text { mixtures }\end{array}$ & $2,02 \pm 0,2$ & $7,24 \pm 0,5$ & $9,26 \pm 0,5$ & $2,71 \pm 0,2^{\mathrm{b}}$ & $12,0 \pm 0,6$ & $1,08 \pm 0,1$ & $4,39 \pm 0,3$ & $5,47 \pm 0,3$ & $0,72 \pm 0,0$ \\
\hline $\begin{array}{l}\text { Mieszaniny } \\
\text { trójskładnikowe } \\
\text { Three component } \\
\text { mixtures }\end{array}$ & $1,97 \pm 0,1$ & $6,96 \pm 0,3$ & $8,93 \pm 0,4$ & $3,08 \pm 0,3^{\mathrm{a}}$ & $12,0 \pm 0,4$ & $1,06 \pm 0,1$ & $4,19 \pm 0,2$ & $5,25 \pm 0,2$ & $0,75 \pm 0,1$ \\
\hline $\begin{array}{c}\text { Prawdopodobieństwo } \\
\text { Probability }\end{array}$ & 0,0001 & 0,0001 & 0,0001 & 0,0001 & 0,0001 & 0,0001 & 0,0001 & 0,0001 & 0,0001 \\
\hline NIR/LSD & 0,283 & 0,735 & 0,803 & 0,330 & 0,822 & 0,187 & 0,601 & 0,625 & 0,061 \\
\hline \multicolumn{10}{|c|}{2016 rok zbioru / 2016 harvest year } \\
\hline $\begin{array}{l}\text { Odmiany } \\
\text { Varieties }\end{array}$ & $2,27 \pm 0,2^{\mathrm{a}}$ & $6,53 \pm 0,6$ & $8,80 \pm 0,5$ & $3,18 \pm 0,4$ & $12,0 \pm 0,8$ & $1,17 \pm 0,1^{\mathrm{a}}$ & $3,96 \pm 0,3$ & $5,13 \pm 0,3$ & $0,69 \pm 0,0$ \\
\hline $\begin{array}{l}\text { Mieszaniny } \\
\text { trójskładnikowe } \\
\text { Three component } \\
\text { mixtures }\end{array}$ & $2,10 \pm 0,1^{\mathrm{b}}$ & $6,82 \pm 0,6$ & $8,92 \pm 0,6$ & $3,13 \pm 0,3$ & $12,0 \pm 0,7$ & $1,05 \pm 0,1^{\mathrm{b}}$ & $4,18 \pm 0,3$ & $5,23 \pm 0,3$ & $0,69 \pm 0,0$ \\
\hline $\begin{array}{l}\text { Prawdopodobieństwo } \\
\text { Probability }\end{array}$ & 0,0001 & 0,0001 & 0,0001 & 0,0001 & 0,0001 & 0,0001 & 0,0001 & 0,0001 & 0,0001 \\
\hline NIR/LSD & 0,177 & 0,428 & 0,419 & 0,256 & 0,520 & 0,123 & 0,321 & 0,319 & 0,087 \\
\hline \multicolumn{10}{|c|}{2018 rok zbioru / 2018 harvest year } \\
\hline $\begin{array}{l}\text { Odmiany } \\
\text { Varieties }\end{array}$ & $2,01 \pm 0,2$ & $6,86 \pm 0,6^{\mathrm{b}}$ & $8,87 \pm 0,5^{\mathrm{b}}$ & $3,30 \pm 0,4$ & $12,2 \pm 0,8$ & $0,88 \pm 0,1$ & $4,24 \pm 0,3^{b}$ & $5,13 \pm 0,2^{b}$ & $0,66 \pm 0,0$ \\
\hline $\begin{array}{l}\text { Mieszaniny } \\
\text { trójskładnikowe } \\
\text { Three component } \\
\text { mixtures }\end{array}$ & $2,03 \pm 0,2$ & $7,57 \pm 1,0^{\mathrm{a}}$ & $9,60 \pm 1,1^{\mathrm{a}}$ & $3,02 \pm 0,5$ & $12,6 \pm 1,1$ & $0,89 \pm 0,1$ & $4,50 \pm 0,4^{\mathrm{a}}$ & $5,40 \pm 0,4^{\mathrm{a}}$ & $0,64 \pm 0,0$ \\
\hline $\begin{array}{c}\text { Prawdopodobieństwo } \\
\text { Probability }\end{array}$ & 0,0001 & 0,0001 & 0,0001 & 0,0001 & 0,0001 & 0,0001 & 0,0001 & 0,0001 & 0,0001 \\
\hline NIR/LSD & 0,222 & 0,662 & 0,752 & 0,314 & 0,903 & 0,071 & 0,354 & 0,371 & 0,096 \\
\hline
\end{tabular}

S-NSP - rozpuszczalne nieskrobiowe polisacharydy/soluble nonstarch polysaccharides; I-NSP - nierozpuszczalne nieskrobiowe polisacharydy/insoluble nonstarch polysaccharides; NSP - nieskrobiowe polisacharydy/nonstarch polysacchrides; TDF - włókno pokarmowe ogólem/total dietary fibre; WE-AX - arabinoksylany ekstrahowalne $w$ wodzie/water extractable arabinoxylans; WUE-AX arabinoksylany nieekstrahowalne $w$ wodzie/water unextractable arabinoxylans; TAX-arabonoksylany ogótem/total arabinoxylans 
rolę podczas wypieku (Hoseney, 1994). Zawartość skrobi w mieszaninach odmianowych trójskładnikowych $\mathrm{w}$ badanym materiale mieściła się w zakresie od 56,6\% (mieszanka Goplana+Jarlanka+Rusałka z 2016 roku) do 67,4\% (mieszanka Izera+Ostka Smolicka+Struna z 2014 roku), przy wartościach średnich $\mathrm{z}$ poszczególnych lat badań $66,2 \%, 60,3 \%$ i 59,2\%. Mieszaniny trójskładnikowe z 2014 roku miały średnio w ziarnie istotnie więcej skrobi niż ziarno odmian z siewu czystego $(66,2 \%$ vs. $65,3 \%)$. Odwrotne zależności wykazano w odniesieniu do ziarna z 2018 roku zbioru, mieszaniny odmian miały średnio istotnie mniej skrobi niż odmiany, odpowiednio 59,2\% i 60,7\%. Takich powiązań nie uzyskano $\mathrm{w}$ ziarnie pochodzącym z 2016 roku.

Ziarno pszenicy jest w naszej diecie ważnym źródłem błonnika pokarmowego i innych substancji o właściwościach prozdrowotnych (Shewry i in., 2010; Jones, 2010). Błonnik pokarmowy stanowi kompleks heterogennych substancji, odpornych na działanie enzymów trawiennych obecnych w przewodzie pokarmowym człowieka. $\mathrm{Z}$ chemicznego punktu widzenia w skład błonnika pokarmowego wchodzą nieskrobiowe polisacharydy, którymi w przypadku pszenicy są głównie arabinoksylany, a ponadto oligosacharydy, skrobia oporna, kwasy uronowe i lignina. W ziarnie pszenicy występują tylko niewielkie ilości oligosacharydów, kwasów uronowych i skrobi opornej, dlatego w niniejszych badaniach pominięto ich oznaczenie. Uzyskane wyniki pokazały relatywnie duże $\mathrm{i}$ istotne zróżnicowanie odmianowe zawartości TDF i jego składników w ziarnie z poszczególnych lat zbioru (tab.5). Największe różnice stwierdzono w zawartości arabinoksylanów, w szczególności ich frakcji rozpuszczalnej w wodzie. Współczynniki zmienności dla tego składnika błonnika pokarmowego wynosiły odpowiednio $15 \%, 9 \%$ i $13 \%$ w ziarnie z 2014, 2016 i 2018 roku, zbioru. Zróżnicowanie zawartości TDF i jego składników w ziarnie odmian z siewu czystego miało istotny wpływ na ich zawartość w mieszankach. Chociaż ogólnie wartości średnie TDF były podobne w latach badań, w zakresie $12,0-12,6 \%$, istotne różnice w zawartości TDF wykazano w ziarnie z każdego roku zbioru. Podobnie istotne różnice stwierdzono w każdym roku badań dla poszczególnych składników błonnika: frakcji S-NSP, I-NSP, NSP, ligniny a także arabinoksylanów i $\beta$-glukanu. Odmiany Arabella i Ostka Smolicka ze zbioru 2014 roku miały istotnie więcej TDF (12,6\%) niż odmiany Struna i Tybalt (11.5\%). Pośród mieszanin trójskładnikowych, osiem miało istotnie więcej TDF (12,5\%) niż mieszaniny składające się z odmian Izery i Struny z Arabellą bądź z Ostką Smolicką (11,2\%) (rys. 1). W materiale z 2016 roku zbioru, odmiana KWS Torridon charakteryzowała się największą zawartością TDF $(13,1 \%)$ w ziarnie, a odmiany Arabella i Harenda najmniejszą (10,9\% i 11,0\%). Pozostałe odmiany miały tego składnika $\mathrm{w}$ ilości $12,1 \%$ do $12,4 \%$. Mieszanina składająca się z odmian Arabella + Harenda + Kamelia miała najmniej TDF $(10,8 \%)$, natomiast najwięcej $(13,4 \%)$ błonnika było w mieszaninach odmian Harenda+Goplana+Kamelia oraz Goplana+Kamelia+KWS Torridon. Z kolei w materiale pochodzącym z 2018 roku odmiany Frajda i Nimfa odznaczały się największą ilością TDF (13,0\%), mniej miały odmiany Jarlanka (12,5\%) oraz Goplana (12,3\%) i Harenda (11,7\%), a najmniej odmiana Rusałka (10,7\%). Mieszanina składająca się z odmian o największej zawartości TDF (Frajda+Goplana+Nimfa) miała błonnika najwięcej $(15,0 \%)$. W grupie mieszanin o największej ilości TDF znalazły się również mieszanki, które w swym składzie miały odmiany Frajdę i Jarlankę (14,3\%), bądź Frajdę i Goplanę (13,8\% do 14,4\%). Najmniejszymi ilościami TDF charakteryzowały się mieszaniny skomponowane z odmian Rusałka i Harenda (11,5\%-12,1\%), a więc $z$ odmian o istotnie mniejszej ilości TDF. Każdy z oznaczanych składników błonnika wpływał na zróżnicowanie TDF w ziarnie odmian i mieszanek. W największym stopniu zróżnicowanie to było uwarunkowane zawartością nieskrobiowych polisacharydów (NSP), których udział w ogólnej ilości błonnika był największy i stanowił od $73 \%$ do $77 \%$. Współczynniki korelacji między zawartością TDF a zawartością NSP w ziarnie były wysoce istotne $(p<0,01)$ i wynosily odpowiednio $\mathrm{r}=0,812 ; \mathrm{r}=0,885$ i $\mathrm{r}=0.894 \mathrm{w}$ poszczególnych latach zbioru (tab. 6). Arabinoksylany, główne składniki polisacharydowe ziarna pszenicy, mające blisko 50\% udział w TDF, w zakresie od $43 \%$ do $46 \%$ w ziarnie odmian i mieszanek, wpływały również wysoce istotnie na zróżnicowanie zawartości TDF. Współczynniki korelacji między zawartością TDF a zawartością TAX wynosiły $\mathrm{r}=0,800$ w odniesieniu do ziarna z 2014 i 2018 roku zbioru oraz $\mathrm{r}=0,866 \mathrm{w}$ przypadku ziarna z 2016 roku. Wyniki uzyskane w niniejszej pracy w odniesieniu do zawartości błonnika pokarmowego, jego głównych składników, jak również zróżnicowania są podobne do wyników innych autorów, analizujących inny zestaw odmian w innych warunkach produkcji ziarna (Bach Knudsen, 2014; Boros i in., 
A.

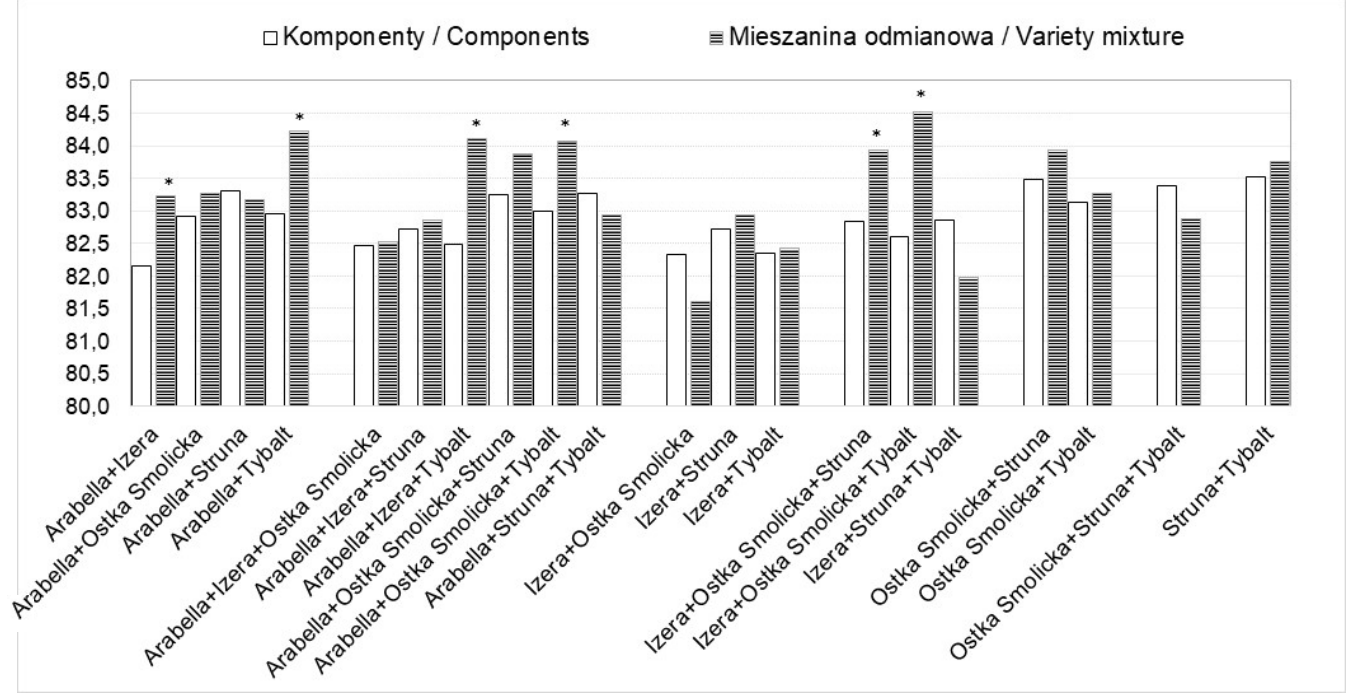

B.

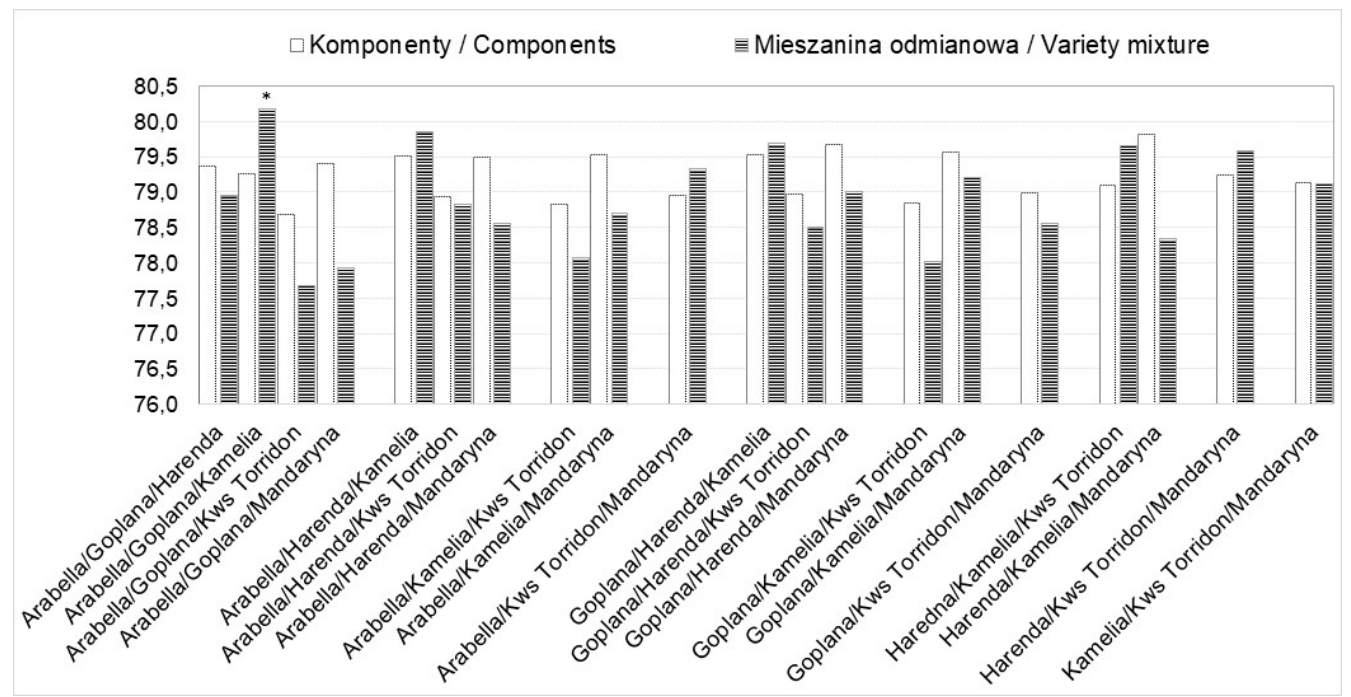

C.

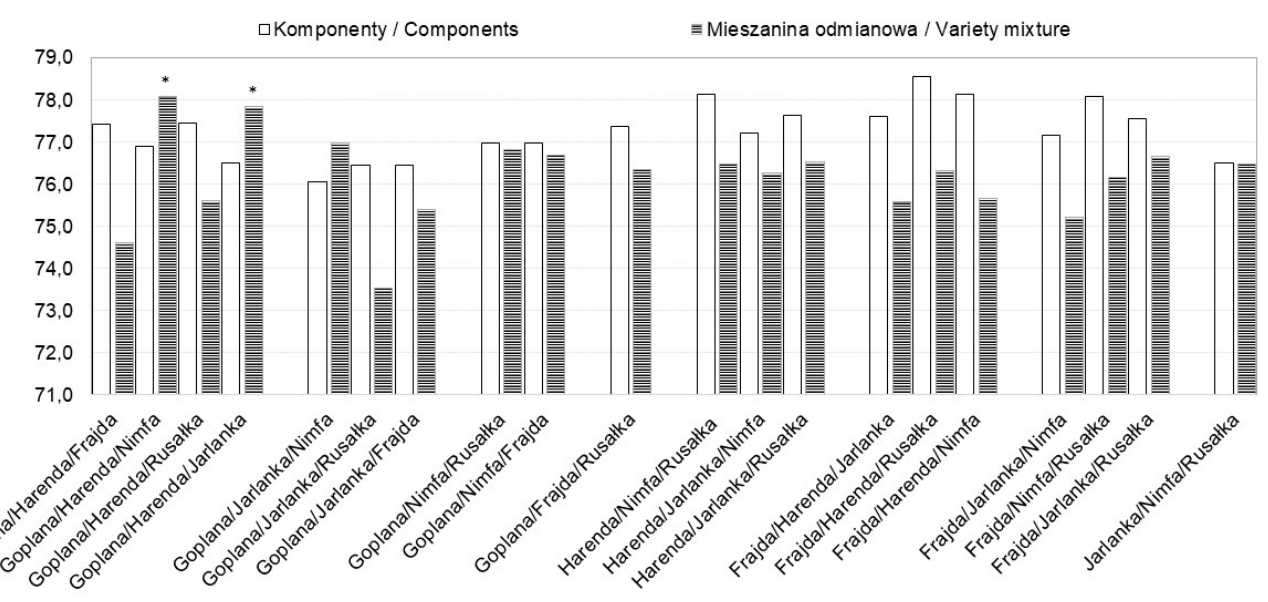

*różnica istotna / *significant difference

Rys. 1. Porównanie sumy składników odżywczych w ziarnie odmian-komponentów z siewu czystego i w mieszaninach dwu i trójskładnikowych z ich udziałem ze zbioru w latach A. 2014; B. 2016 i C. 2018 (dla komponentów - wartość średnia odmian)

Fig. 1. Comparison of the nutrient contents in pure varieties and in their two or three component mixtures from harvest in years A. 2014; B. 2016 and C. 2018 ( for component - varieties average value) 
2015).

Spożywając produkty całoziarnowe dostarczamy organizmowi oprócz błonnika również całą gamę substancji biologicznie aktywnych, do których zalicza się $\mathrm{m}$. in. polifenole, w tym alkilorezorcynole (Vitaglione, Fogliano, 2010). $\mathrm{Z}$ tego względu Jones (2010) uważa je za substancje współtowarzyszące błonnikowi. Dla roślin są one niezbędne do wzrostu i rozwoju, adaptacji do stresów biotycznych i abiotycznych oraz obrony przed tymi stresami. W żywności odpowiadają za jej barwę, smak, zapach oraz właściwości przeciwutleniające, przeciwzapalne, przeciwbakteryjne, przeciwnadciśnieniowe, immunostymulujące, hipocholesterolowe i antynowotworowe (Jones, 2010; Vitaglione, Fogliano, 2010). Zboża są głównym źródłem substancji biologicznie aktywnych $\mathrm{W}$ naszej diecie (Jones, 2010). W przeprowadzonych badaniach wykazano istotne różnice w zawartości związków fenolowych ogółem (TPC) oraz alkilorezorcynoli (AR) w ziarnie odmian pochodzącym z każdego roku zbioru (tab. 7). W ziarnie z 2014 roku, zawartość TPC mieściła się w zakresie $1,1-1,4 \mathrm{mg} / \mathrm{g}$, a AR $470-570 \mathrm{mg} / \mathrm{g}$ ziarna, przy współczynniku zmienności równym $10 \%$ i $6 \%$. Ostka Smolicka i Izera były odmianami o istotnie większej ilości TPC i AR, odpowiednio $1,5 \mathrm{mg} / \mathrm{g}$ i $570 \mathrm{mg} / \mathrm{g}$, w porównaniu do pozostałych odmian. Większe ilości TPC oraz AR stwierdzono w ziarnie odmian pochodzącym z 2016 roku, w zakresie $1,3-1,9 \mathrm{mg} / \mathrm{g}$, oraz $400-680 \mathrm{mg} / \mathrm{g}$ ziarna, przy zmienności, odpowiednio $17 \%$ i $18 \%$. Goplana i Kamelia były odmianami o największej ilości TPC (1,9 i $1,8 \mathrm{mg} / \mathrm{g})$, a Kamelia z KWS Torridon o największej ilości AR (680 i $610 \mathrm{mg} / \mathrm{g}$ ). Ziarno odmian z 2018 roku zbioru miało znacznie zbliżone zawartości TPC i AR, w zakresie 1,3-1,5 mg/g oraz $440-490 \mathrm{mg} / \mathrm{g}$, stąd zmienność tych cech była również mała, odpowiednio 4\% i 3\%. W ziarnie z 2018 roku zbioru, nie stwierdzono istotnych różnic wśród odmian pod względem ilości TPC, a odmianą o największej zawartości polifenoli była Rusałka. W odniesieniu do zawartości AR w ziarnie odmiana Frajda miała istotnie więcej tych związków niż odmiany Goplana (455 mg/g), Harenda (452 mg/g) i Rusałka (441 mg/g). Ze względu na niewielkie ilości związków fenolowych $\mathrm{w}$ ziarnie odmian pszenicy z siewu czystego, mimo niekiedy dużego zróżnicowania $\mathrm{w}$ obrębie badanego materiału, trudno jednoznacznie wskazać czy poziom ich w odmianach miał wpływ na zawartość zarówno TPC jak i AR w ziarnie mieszanin odmianowych. Ziarno mieszanin odmianowych z 2018 roku zbioru miało średnio istotnie więcej TPC $(1,46 \mathrm{mg} / \mathrm{g})$, w tym alkilorezorcynoli $(494 \mathrm{mg} / \mathrm{kg})$, niż ziarno odmian wchodzących w skład mieszanek, zawierające wymienione związki fenolowe w ilościach, odpowiednio 1,40 mg/g; $459 \mathrm{mg} / \mathrm{kg}$. Przeciwnie, w mieszankach odmianowych z 2014 roku zbioru zawartość obu związków fenolowych w ziarnie była niższa, przy czym w przypadku AR różnica była istotna (522 vs. $452 \mathrm{mg} / \mathrm{kg}$ ). Nie stwierdzono różnic istotnych między wartościami średnimi odmian z siewu czystego, a wartościami średnimi mieszanin odmianowych $\mathrm{w}$ zawartości związków fenolowych w ziarnie ze zbioru 2016 roku. Ilości związków fenolowych uzyskane w niniejszych badaniach są zbieżne z wynikami innych autorów w odniesieniu do odmian uprawnych pszenicy jarej (Vitaglione, Fogliano, 2010; Boros i in., 2015).

Zróżnicowanie genetyczne zawartości błonnika pokarmowego oraz jego składników wskazuje,

Wspólczynniki korelacji r-Pearsona między wybranymi skladnikami ziarna pochodzącego z trzech lat zbioru

Person's correlation coefficients of grain components in three years of harvest

\begin{tabular}{c|c|c|c}
\hline \multirow{2}{*}{$\begin{array}{c}\text { Składniki porównywane } \\
\text { Components compared }\end{array}$} & 2014 & 2016 & 2018 \\
\cline { 2 - 4 } & $-0,316$ & $-0,524^{*}$ & $-0,450^{*}$ \\
\hline Białko - skrobia / Prptein - starch & $0,761^{* *}$ & $0,835^{* *}$ & $0,890^{* *}$ \\
I-NSP - TDF & 0,382 & $-0,083$ & 0,112 \\
S-NSP - TDF & $0,812^{* *}$ & $0,885^{* *}$ & $0,894^{* *}$ \\
NSP - TDF & $0,800^{* *}$ & $0,866^{* *}$ & $0,799^{* *}$ \\
TAX - TDF & & \multicolumn{3}{|c}{ Rok zioru / Harvest year } \\
\hline
\end{tabular}

I-NSP - nierozpuszczalne nieskrobiowe polisacharydy/insoluble nonstarch polysaccharides; S-NSP rozpuszczalnenieskrobiowe polisacharydy/solublenonstarch polysaccharides; NSP-nieskrobiowe polisacharydy/ nonstarch polysacchrides; TDF - włókno pokarmowe ogótem/total dietary fibre; TAX-arabonoksylany ogótem/ total arabinoxylans

*Istotny przy $p<0,05 /$ Signifcant at $p<0,05 ; * *$ Istotny przy $p<0,01$; Signifcant at $p<0,01$ 
że poprzez dobór odmian można kształtować zarówno ilość, jak i skład TDF w mieszankach odmianowych pszenicy jarej, stosownie do kierunku wykorzystania ziarna. Odpowiedni dobór odmian umożliwi produkcję surowca spełniającego wymogi przemysłu zbożowo-młynarskiego i piekarniczego o poprawionych właściwościach prozdrowotnych, a $\mathrm{z}$ drugiej strony surowca wysokiej jakości dla przemysłu paszowego, o dużej zawartości składników odżywczych, w połączeniu z obniżoną zawartością składników antyżywieniowych. Nietrawiony w przewodzie pokarmowym kompleks TDF, jeśli jest obecny $\mathrm{w}$ mieszance paszowej $\mathrm{w}$ nadmiernej ilości, w szczególności pod względem zawartości frakcji arabinoksylanów rozpuszczalnych w wodzie, przyczynia się do zmniejszenia spożycia paszy, obniżenia strawności składników odżywczych i przyswajalności, a w efekcie pogorszenia parametrów produkcyjnych karmionych zwierząt (Choct, Annison, 1992). Uznaje się go więc za składnik antyżywieniowy w paszach dla zwierząt nieprzeżuwających, gdyż w produkcji zwierzęcej liczy się przede wszystkim efekt ekonomiczny.

Z przeprowadzonych badań wynika, że pewne kombinacje odmian mogą efektywniej wykorzystywać zasoby środowiska niż ich monokultury. Przekłada się to nie tylko na większy plon ziarna mieszanek odmianowych, ale także na jego wartość użytkową. Uprawę mieszanek odmianowych cechuje potencjał, dzięki któremu możliwe jest zwiększenie wartości użytkowej i odporności ziarna pszenicy jarej, dlatego też identyfikacja odpowiedniej kombinacji genotypów pod tym kątem wymaga dalszych, bardziej ukierunkowanych badań.

Tabela 7

Table 7

Zawartość związków fenolowych ogółem (TPC), w tym alkilorezorcynoli w ziarnie odmian i ich mieszanin odmianowych pszenicy jarej (wartości średnie z poszczególnych lat zbioru)

Content of total phenolic compounds (TPC) and alkylresorcinols in varieties and variety mixtures of spring wheat (mean values of particular harvest years)

\begin{tabular}{|c|c|c|}
\hline $\begin{array}{l}\text { Odmiany, mieszanki } \\
\text { Varieties, mixtures }\end{array}$ & $\begin{array}{c}\text { TPC } \\
\text { [mg GAE/g s.m.] } \\
\text { [mg GAE/g DM] }\end{array}$ & $\begin{array}{l}\text { Alkilorezorcynole }[\mathrm{mg} / \mathrm{kg}] \\
\text { Alkylresorcinols }[\mathrm{mg} / \mathrm{kg}]\end{array}$ \\
\hline \multicolumn{3}{|c|}{2014 rok zbioru/2014 harvest year } \\
\hline $\begin{array}{l}\text { Odmiany } \\
\text { Varieties }\end{array}$ & $1,33 \pm 0,1$ & $522 \pm 33^{a}$ \\
\hline $\begin{array}{l}\text { Mieszaniny dwuskładnikowe } \\
\text { Two component mixtures }\end{array}$ & $1,26 \pm 0,1$ & $491 \pm 25^{\mathrm{a}}$ \\
\hline $\begin{array}{l}\text { Mieszaniny trójskładnikowe } \\
\text { Three component mixtures }\end{array}$ & $1,27 \pm 0,1$ & $452 \pm 41^{\mathrm{b}}$ \\
\hline $\begin{array}{l}\text { Prawdopodobieństwo } \\
\text { Probability }\end{array}$ & 0,0001 & 0,0001 \\
\hline NIR/LSD & 0,203 & 40,2 \\
\hline \multicolumn{3}{|c|}{2016 rok zbioru/2016 harvest year } \\
\hline $\begin{array}{l}\text { Odmiany } \\
\text { Varieties }\end{array}$ & $1,55 \pm 0,2$ & $574 \pm 94$ \\
\hline $\begin{array}{l}\text { Mieszaniny trójskładnikowe } \\
\text { Three component mixtures }\end{array}$ & $1,54 \pm 0,1$ & $595 \pm 70$ \\
\hline $\begin{array}{l}\text { Prawdopodobieństwo } \\
\text { Probability }\end{array}$ & 0,0001 & 0,0001 \\
\hline NIR/LSD & 0,123 & 54,1 \\
\hline \multicolumn{3}{|c|}{2018 rok zbioru/2018 harvest year } \\
\hline $\begin{array}{l}\text { Odmiany } \\
\text { Varieties }\end{array}$ & $1,40 \pm 0,0^{b}$ & $459 \pm 0,1^{b}$ \\
\hline $\begin{array}{l}\text { Mieszaniny trójskładnikowe } \\
\text { Three component mixtures }\end{array}$ & $1,46 \pm 0,1^{\mathrm{a}}$ & $494 \pm 0,1^{\mathrm{a}}$ \\
\hline $\begin{array}{l}\text { Prawdopodobieństwo } \\
\text { Probability }\end{array}$ & 0,0042 & 0,0001 \\
\hline NIR/LSD & 0,222 & 31,6 \\
\hline
\end{tabular}




\section{Wnioski}

1. Większość wewnątrzgatunkowych mieszanek pszenicy jarej plonowała wyżej w porównaniu do średniego plonu komponentów uzyskanego z siewu czystego oraz charakteryzowała się lepszą zdrowotnością. Wskazuje to na bardziej efektywne wykorzystanie zasobów środowiska przez mieszaniny odmianowe niż przez poszczególne odmiany wysiewane w monokulturze.

2. Kompleksowe wyniki oceny składu chemicznego ziarna pokazały, że poprawa wartości użytkowej ziarna jest możliwa poprzez uprawę mieszanek odmianowych pszenicy jarej.

3. Czynnik genetyczny miał istotny wpływ na zawartość substancji odżywczych oraz kompleksu błonnika pokarmowego w ziarnie mieszanin odmianowych pszenicy jarej. Identyfikacja odpowiednich odmian do siewów mieszanych jest niezbędna do poprawy wartości użytkowej ziarna pszenicy jarej.

4. Przydatność odmian pszenicy jarej do siewu mieszanego zaleca się oceniać kompleksowo, jako wypadkową oceny polowej z wynikami badań składu chemicznego ziarna.

Badania wykonano $w$ ramach zadania 2.10, Programu Wieloletniego IHAR-PIB na lata 2015-2020, sfinansowane przez MRiRW.

\section{Literatura}

AACC. (2011). Approved Methods of Analysis, 11th Ed. Cereals \& Grains Association, St. Paul, MN, U.S.A.

Achremowicz, B., Berski, W., Gambus, H. (2010) Wykorzystanie metody SRC (Solvent Retention Capacity) do oceny jakości technologicznej mąk pszennych. Żywność. Nauka. Technologia. Jakość. 6 (73), 34-45.

Bach Knudsen, K. E. (2014). Fiber and nonstarch polysaccharide content and variation in common crops used in broiler diets. Poultry Sci. 93, 2380-2393.

Biel, W., Maciorowski, R. (2012). Ocena wartości odżywczej ziarna wybranych odmian pszenicy. Żywność. Nauka. Technologia. Jakość. 2 (81), 45-55.

Boros, D., Gołębiewski, D., Myszka, K. (2014). Wstępne badania ziarna wybranych rodów hodowlanych pszenicy jako surowca do słodowania. Żywność. Nauka. Technologia. Jakość. 3 (94), 151-164.

Boros, D., Fraś, A., Gołębiewska, K., Gołębiewski, D., Paczkowska, O., Wiśniewska, M. (2015). Wartość odżywcza i właściwości prozdrowotne ziarna odmian zbóż i nasion rzepaku zalecanych do uprawy w Polsce. Monografie i Rozprawy Naukowe IHAR-PIB. 49, 1-119.

Cacak-Pietrzak, G., Ceglińska, A., Jończyk, K. (2014). Wartość wypiekowa mąki z ziarna odmian pszenicy upra- wianych wekologicznym systemie produkcji. Zesz. Probl. Post. Nauk Roln. 576, 23-32

Cheema, N. M., Chowdhry, M. A., Gliddon, C. J. (1988). Varietal blends and their performance in spring wheat. Pakistan J. Agric. Res. 9, 141-146.

Choct, M., Annison, G. (1992). The inhibition of nutrient digestion by wheat pentosans. Brit. J. Nutr. 67, 123-132.

COBORU. Wyniki doświadczeń odmianowych. Pszenica zwyczajna jara (dobór komponentów do mieszanek), 2014, 2015; 2016; 2018.

COBORU. (2020). Lista opisowa odmian roślin rolniczych. Zbożowe.

Cygankiewicz, A. (1997). Skuteczność wstępnej oceny ziarna rodów i odmian wzorcowych pszenicy w oparciu o wartości liczbowe sedymentacji i procentową zawartość białka w porównaniu do wskaźników pełnej oceny. Biul. IHAR. 204, 237-243.

Dai, J., Wiersma, J. J., Holen, D. L. (2012). Performance of hard red spring wheat cultivar mixtures. Agron. J. 104 (1), 17-21.

Englyst, H. N., Cummings, J. H. (1984). Simplified method for the measurement of total non-starch polysaccharides by gas-liquid chromatography of constituent sugars as alditol acetates. Analyst. 109, 937-942.

Finckh, M. R., Gacek, E. S., Goyeau, H., Lannou, C., Merz, U., Mundt, C. C., Munk, L., Nadziak, J., Newton, A. C., Vallavieille-Pope, C., Wolfe, M. S. (2000). Cereal variety and species mixtures in practice, with emphasis on disease resistance. Agronomie, EDP Sci. 20, 813-837.

Gacek, E., Czembor, H. J., Nadziak, J. (1996). Wpływ zróżnicowania genetycznego w mieszaninach i mieszankach zbożowych na rozwój chorób i plonowanie. Biul. IHAR. 200, 203-209.

Gajda, A., Kulawinek, M., Kozubek, A. (2008). An improved colorimetric method for the determination of alkylresorcinols in cereals and whole-grain cereal products. J. Food Compos. Anal. 21, 428-434.

Hoseney, R. C. (1994). Principle of cereal science and technology. American Association of Cereal Chemists, Inc. St. Paul, MN.

Jones, J. M. (2010). Dietary fibre's co-passengers: is it the fibre or the co-passengers? In: J.W. van der Kamp, J.M. Jones, B.V. Mccleary, D.L Topping (eds.), Dietary fibre: new frontiers for food and health (pp. 365-378). Wageningen Academic Publishers.

Jost, M., Samobor, V., Drobac, L. (2015). The role of wheat cultivars blend on grain yield and baking quality. Am. J. Agric. Sci. 2 (5), 203-207.

Kiær, L. P., Skovgaard, I. M., Østergård, H. (2009). Grain yield increase in cereal variety mixtures: A meta-analysis of field trials. Field Crops Res. 114, 361-373.

Lee, K. M., Shroyer, J. P., Herrman, T. J., Lingenfelser, J. (2006). Blending hard white wheat to improve grain yield and end-use performance. Crop Sci. 46, 1124-1129. 
Leszczyńska, D. (2010). Stan i uwarunkowania uprawy mieszanek zbożowych w Polsce. J. Res. Appl. Agric. Eng. $55,7-11$.

Munck, L. (1987) Breeding for quality in barley - Experiences and perspectives. In: Barley genetics V. S. Yasuda and T. Konishi eds. Maruzen Co. Ltd. Okayama, Japan 753-762.

Nadziak, J., Tratwal, A. (2012). Określenie przydatności odmian do uprawy w zasiewach mieszanych pszenicy ozimej. Biul. IHAR. 264, 49-54.

Rocznik Statystyczny Rolnictwa 2019. (2020). Główny Urząd Statystyczny, Warszawa.

Rothkaehl, J. (2015). Jakość ziarna pszenicy ze zbiorów 2014 roku w Polsce. Przegl. Piekarski i Cukierniczy, 5, 10-14.

Shewry, P. R.. Saulnier, L., Fuillon, F., Gebruers, K., Courtin, C., Delcour, J., Toole, G., Boros, D., Salse, J., Ravel, C., Mills, E. N. C., Ward, J. L., Charmet, G. (2010). Improving the benefits of wheat as a source of dietary fibre. In: J.W. van der Kamp, J. M. Jones, B. V. Mccleary, D. L Topping (eds.), Dietary fibre: new frontiers for food and health (pp. 65-78). Wageningen Academic Publishers.

Singleton, V. L., Rossi, J. A. (1965) Colorimetry of total phenolics with phosphomolybdic-phosphotungstic acid reagents. Am. J. Enol.Vitic. 16: I44-I58.

Stępniewska, S., Słowik, E. (2016). Ocena wartości technolo- gicznej wybranych odmian pszenicy ozimej i jarej. Acta Agrophysica. 23 (2), 275-286.

Theander, O., Westerlund, E. A., (1986). Studies on dietary fiber. 3. Improved procedures for analysis of dietary fiber. J. Agric. Food Chem. 34 (2), 330-336.

Tłuścik, F., Kozubek, A., Mejbaum-Katzenellebogen, W. (1981). Alkylresorcinols in rye (Secale cereale L.) grains. VI. Colorimetric micromethod for the determination of alkylresorcinols with the use of diazonium salt, Fast Blue B. Acta Soc. Bot. Polon. 50, 645-651.

Vera, C. L., Fox, S. L., DePauw, R. M., Smith, M. A. H., Wise, I. L., Clarke, F. R., Procunier, J. D., Lukow, O. M. (2013). Relative performance of resistant wheat varietal blends and susceptible wheat cultivars exposed to wheat midge, Sitodiplosis mosellana (Géhin). Can. J. Plant Sci. 93, 59-66.

Vitaglione, P., Fogliano, V. (2010). Cereal fibres, antioxidant activity and health. In: J.W. van der Kamp, J.M. Jones, B.V. Mccleary, D.L Topping (eds.), Dietary fibre: new frontiers for food and health (pp. 379-393). Wageningen Academic Publishers.

Żmijewski, M. (2004). Wartość technologiczna ziarna odmian pszenicy jarej uprawianej w siewie czystym i mieszanym oraz przy stosowaniu fungicydów. Żywność. Nauka. Technologia. Jakość. 1 (3), 74-83. 
